\title{
KEBERISLAMAN KELOMPOK MAJELIS ILMI AL-AMIN DI KABUPATEN BOALEMO
}

\section{ISLAMIC ATTITUDE OF MAJELIS ILMI AL-AMIN GROUP IN BOALEMO REGENCY}

\author{
Sitti Arafah \\ Balai Penelitian dan Pengembangan Agama Makassar \\ Jl. A.P. Pettarani No. 72 Makassar \\ Email: arafahlitbang@yahoo.com
}

Naskah diterima tanggal 17 Januari 2018. Naskah direvisi tanggal 28 Februari 2018. Naskah disetujui tanggal 18 Mei 2018

\begin{abstract}
Abstrak
Penelitian ini bertujuan untuk mendeskripsikan kelompok Majelis Ilmi Al-Amin. Oleh pembimbingnya mengklaim telah menerima ilham, hidayah bahkan menyebutnya "wahyu", mengenai ilmu kegaiban melalui proses dialog. Proses penelusuran data dengan menggunakan wawancara, observasi dan dokumentasi. Hasil penelitian menunjukkan bahwa kelompok Majelis Ilmi Al-Amin telah eksis sejak tahun 2007 hingga kini, walaupun telah mengalami aksi kekerasan berupa pelemparan dan pengusiran oleh masyarakat hingga akhirnya kelompok ini harus berpindah tempat untuk melakukan aktivitas pengajian. Masyarakat dan pemerintah menganggap kelompok Majelis Ilmi Al-Amin memiliki pemahaman keberislaman yang menyimpang, seperti shalat yang tidak lagi dilakukan secara nyata, puasa berada pada tingkatan shaumul khawasul bil khawas dan berhaji tidak perlu ke Mekkah.
\end{abstract}

Kata kunci: keberislaman, majelis ilmi al-amin, boalemo,

\begin{abstract}
The study on aims to discribe assemblies Ilmi Al-Amin gorup. By his counselors claiming to have received inspiration, hidayah even call it "revelation" of learning magic trrought the process of dialogue. The process of data tracing using interview, observation and documentation. The result of study show that the Al-Amin Assembly group has existed sice 2007 until now, despite experiencing violence in the from of throwing and expulsion by the community until finally had to move place to conduct activities. Society and government assume that the assembly group Ilmi Al-Amin has a distorted understanding of Islam, such as prayer that is no longer done in real, fasting has been at the level of khawaisul khawas and pilgrimage does not need to Mecca.
\end{abstract}

Keyword: Islam, the assembly of Ilmi Al-Amin, Boalemo

\section{PENDAHULUAN}

$\mathrm{P}$ ergulatan manusia dengan agama sampai hari ini tidak selesai pada titik kepuasaan dengan adanya agama-agama mainstream, dibalik itu tetap saja manusia mencari bentuk-bentuk lain dan semangat lain baik yang masih memiliki ciri dari agama yang mereka anut sebelumnya atau melakukan konversi agama. Atas fenomena lahirnya konversi ini yang dalam konteks ke Indonesiaan mengalami dua periode rezim dengan kendali yang berbeda atas "agama" berimplikasi pada respon masyarakat agama itu sendiri mengeindentifikasi diri sebagai bagian dari kelompok tertentu. Orde baru dengan ciri khas stabilitas nasional dan kendali ketat untuk setiap tindakan penduduk termasuk dalam berkeyakinan dan beragama tampak "sukses" untuk mengidentifikasi keberagamaan penduduknya pada dua besaran, beragama formal dan berkeyakinan (Nugraha, 2016: 230).

Dinamika keagamaan di Indonesia berlangsung cukup tinggi sejak 15 tahun terakhir, tepatnya pasca reformasi. Organisasi keagamaan baru secara khusus yang muncul dalam Islam, mereka tampil dengan berbagai bentuk baik secara ekslusif seperti An-Nadzir, Penganut AlQuran Sejati, Ajaran Keselamatan Versi Sumardi, GAFATAR, Paruru dan sebagainya. Ada pula yang tampil secara ekspresif seperti FBI (Front Pembela Islam), dan adapula dalam bentuk radikal, 
demikian pula aliran yang sudah lama di Indonesia pun kembali bergeliat namun sering mendapatkan respon yang negative seperti Ahmadiyah atau Syi'ah. Oleh karena itu, reformasi menjadi stimulan bagi setiap kelompok agama yang akan memunculkan diri dalam ragam bentuk yang berlainan (Saprillah. $\mathrm{dkk}, 2017: 178)$.

Suatu aliran maupun paham keagamaan seringkali muncul sekaligus sebagai gerakan keagamaan. Sebagai suatu gerakan keagamaan, terkadang aliran keagamaan tersebut mengklaim diri sebagai penyelamat umat dari dekadensi moral yang melanda masyarakat dari keterpurukan ekonomi. Dalam konteks ini, gerakan keagamaan dapat mengusung konsep "ratu adil" yang menjanjikan suatu penyelamatan atau pembebasan dari segala keterpurukan. Dan dengan keterpurukan ekonomi maupun politik dan berbagai kesulitan lain dalam masyarakat akan menjadi lahan subur bagi perkembangan gerakan keagamaan yang tergolong sempalan itu (Al-Hakim (ed), 2009: iii).

Munculnya kelompok yang dianggap sempalan akan berpontesi melahirkan konflik. Mereka hadir membawa paham dan praktik keagamaan yang berbeda dengan yang dianut kebanyakan umat di Indonesia dan secara kuantitas jumlah mereka sangat sedikit. Disisi lain, kehadiran kelompok atau paham yang berbeda ini akan membawa pada sikap destuktif. Oleh karena itu, dibutuhkan suatu desain politik keagamaan agar mereka dapat mengatur "lalu lintas" politik keagamaan agar mereka dapat hidup dalam situasi kondusif, dengan memperhatikan aspek-aspek dasar dalam teologi Islam (Sunar, 2012:75).

Kebhinekaan agama dan keimanan adalah kehendak Allah yang tak bisa kita tolak atau dihindari. Setiap orang berhak dan sepantasnya berbangga dengan agama dan keyakinannya tanpa harus menuding keyakinan orang lain sebagai kepalsuan dan kesesatan. Agama sebagai "keyakinan" adalah sesuatu yang tersembunyi direlung hati; tidak seorang pun bisa mengetahui secara persis sosok dan anatomi keyakinan orang lain. Menghakimi keyakinan orang lain adalah absurd dan tak bisa diterima akal sehat. Khalifah Umar bin Khataab RA berkata "Nahnu nahkum bidzzhawahir wallahu yatawallas saraair (kita manusia hanya bisa menghakimi yang tampak, sementara perihal yang tersembunyi (keimanan) dalam hati, Allah saya yang mengetahui) (Ubaid (ed), 2015:100).
Kabupaten Boalemo sebagai salah satu wilayah yang dinamis dengan tingkat kemunculan berbagai organisasi, kelompok dan paham keagamaan yang membawa pada stigma negatif dari masyarakat bahkan terjadi penyerangan oleh masyarakat salah satu di antaraya adalah kelompok Majelis Ilmi AlAmin, di mana paham dan praktik keagamaan dianggap berbeda dengan masyarakat lainnya. Dalam konteks penelitian ini, gerakan dan paham keagamaan baru yang dianggap menyimpang dan telah dilakukan pembubaran oleh MUI dan Pemerintah setempat, bahkan kini tetap melakukan aktivitasnya.

Oleh karena itu, maka perlu melakukan penelusuran dan pendalaman terhadap kelompok Majelis Ilmi Al-Amin untuk membaca fenomena sistem keberagamaan di Indonesia. Berdasarkan latarbelakang tersebut, maka permasalahan yang akan diangkat dalam penelitian ini adalah (1) Bagaimana kemunculan kelompok Majelis Ilmi AlAmin (2) Bagaimana paham keagamaan Majelis Ilmi Al-Amin?

Adapun tujuan dan kegunaan dari penelitian ini: (1) untuk mengetahui profil paham Majelis Ilmi Al-Amin, (2) untuk mengetahui paham keagamaan dan ajaran kelompok majelis Ilmi Al-Amin. Secara praktis penelitian ini diharapkan dapat memberikan data dan informasi terhadap aktifitas dan gambaran kehidupan keagamaan masyarakat, terutama pihak pemerintah (Kementerian Agama) dalam memberikan pembinaan keagamaan bagi masyarakat secara intensif. Di samping itu diharapkan dapat menjadi rujukan untuk penelitian terkait kelompok keagamaan.

\section{Tinjauan Pustaka \\ Gerakan Keagamaan Baru}

Salah satu bentuk strategi adaptasi dalam kehidupan beragama adalah lahirnya apa yang disebut dengan aliran dan gerakan keagamaan baru (New Religius Movement), dimana setiap komunitas baru memunculkan seorang tokoh atau pemimpin yang berupaya untuk melakukan perubahan pada tataran spiritual yang lebih baik. Dengan adanya rasa percaya diri yang sangat tinggi sang pemimpin/ pembimbing mengaku mendapatkan wahyu (revelation insight) kemudian memperkenalkan ajaran atau melakukan interpreatsi yang berbeda atau pemaknaan teks-teks yang sangat sempit atau secara harfiah sehingga pada praktiknya ajaran atau paham berbeda dengan yang berlaku di masyarakat. Sebagai akibat maka gerakan atau ajaran tersebut 
dianggap menyimpan atau sesat baik masyarakat dan pada akhirnya akan berhadap-hadapan dengan kelompok yang mainstream, pun akhirnya terjadi penyerangan dan berakhir dengan sebuah konflik adalah keniscayaan. Demikian yang terjadi pada kehadiran kelompok Majelis Ilmi Al-Amin di Desa Tabulo Kecamatan Mananggu Kabupaten Boalemo, hingga kini tetap eksis walaupun mengalami sikap kekerasan berupa pengusiran dan pelemparan oleh warga setempat dan dianggap menyimpang oleh MUI dan pemerintah Kabupaten Boalemo.

Munculnya paham yang menyimpang tentu tidak terlepas dari perkembangan sosial masyarakat yang cepat sehingga menimbulkan perasaan dislokasi (kehilangan tempat dalam masyarakat yang berubah), disorientasi (perasaan kehilangan arah), khususnya dalam hal makna dan tujuan hidup karena sistem dan pranata lama yang tidak lagi dapat dipertahankan) dan deprivasi relative (perasaan tidak ikut serta dalam proses-proses perubahan). Semua ini memerlukan solusi dan jawaban atas masalah. Solusi dan jawaban tersebut sering kali mendorong masing-masing individu untuk mencari dan bergabung dengan siapa saja yang dapat mengakomodasinya, makin sederhana solusi maka akan semakin menarik dan diminati yang tak jarang bermuara pada sikap pengkutusan. Lalu muncul tokoh yang menawarkan solusi yang dianggap muda diterima dan dipahami dan membentuk kelompok kultus berdasarkan karisma pribadi (Nuhrison (ed), 2009:189).

Istilah gerakan keagamaan muncul dalam tradisi anglo-saxon pada akhir abad ke 18. Ketika itu, agama Kristen (juga Katolik) mengalami guncangan "spritial" dengan munculnya beragam aliran dalam gereja. Istilah awal yang digunakan adalah sect dan cult (sekte dan pengkutusan). Istilah ini merupakan representasi dari gerakan keagamaan yang muncul di luar konstruksi pemahaman yang mainstream sering diistilahkan sebagai kelompok zindiq yang kesemuanya menrujuk pada konotasi negative (Saprillah, 2016:2).

Kemunculan berbagai sekte yang terjadi selama abad pertengahan, yang bervariasi dari gerakan-gerakan milenerian kecil-kecilan seperti gerakan Pastoureaux di Perancis pada awal abad ke 13 dan ke 14, sampai kepada gerakan yang terorganisir secara baik dan tegar seperti gerakan Cathari di Bulgaria, Perancis Selatan dan beberapa di antara gerakan -gerakan ini dinilai ada yang menyimpang dan dalam banyak hal bertentangan dengan gereja, seperti gerakan Cathari; sementara yang lainnya sejenis gerakan yang dalam beberapa macam lingkungan bisa diakui sebagai ordo dan tidak diakui sebagai sekte (Scharf, 2004:145).

Aliran dan paham keagamaan adalah "pandangan atau doktrin teologis tertentu". Paham dan aliran baru menjadi masalah ketika berhadapan dengan kelompok mainstream (ortodoksi) dan sering dianggap ajaran sesat. Dalam kamus Oxford English Dictonary ajaran sesat (heresy) atau dikenal sebagai bid'ah (makna aslinya secara harfiah berarti membuat-buat) adalah "pandangan atau doktrin teologis keeagamaan yang dianggap berlawanan atau bertentangan dengan keyakinan atau sistem keagamaan manapun, yang dianggap ortodoks dalam filsafat, politik ilmu, seni dan lain-lain yang berbeda dengan apa yang umumnya diakui sebagai yang berwibawa (Farida, 2015:109).

Bryan Wilson, seorang tokoh utama pendekatan fungsioanlisme dalam sosialogi agama, membuat pembedaan yang berguna antara fungsi manifest dan fungsi agama laten. Fungsi manifest agama adalah untuk memberikan penyelamatan bagi laki-laki dan perempuan, dan khususnya penyelamatan identitas personal atau jiwa yang melampaui kematian biologis. Ritual-ritual dan perilaku keberagamaan pada dasarnya memfokuskan pada ketentuan caracara memperoleh keselamatan, melalui bentukbentuk penyembahan, doa atau meditasi yang memungkinkan orang beriman berkomunikasi dengan Tuhan atau tuhan-tuhan dan bentuk-bentuk perilaku etis yang membawa kehidupan orang beriman atau komunitas beriman pada keselarasan dengan nasib penyelamatan mereka. Sedangkan penyelamatan ultimate dengan pengamalan kehidupan sehari-hari yang meliputi emosi dan tubuh. Ia menawarkan strategi menghadapi ganguan emosional inner dan kondisi spiritual, serta dalam menghadapi ancaman kesejahteraan fisik maupun material kepada individu yang beriman dan komunitas yang melakukan penyembahan, pengertian pemberdayaan semacam ini adalah contoh yang disebut Wilson dengan fungsi agama laten (Connoly (ed), 2016: 284-285).

Secara teoritis aliran keagamaan baru dapat diklasifikasikan dalam dua tipe: Aliran keagamaan bermasalah tipe pertama adalah pengakuan individu atau kelompok yang mendapatkan wahyu secara 
asli (orisinil) dari Tuhan. Wahyu tersebut diyakini berisi nilai dan norma sakral sesuatu agama yang berbeda sama sekali dengan isi kitab suci agama yang ada meliputi teks, konteks, aqidah/ketuhanan (teologi), ibadah (ritual), jejaring, proses penerima dan penerimaan kitab suci (tarikh geneologis), kemasyarakatan (muamalah sosiologis), ahklak, alam semesta, awal dan akhir kehidupan.

Aliran bermasalah tipe kedua adalah pengakuan individu atau kelompok mendapatkan wahyu dari Tuhan. Pemahaman dan penafsiran baru atas nilai atau norma sakral sebahagian (modifikasi) dari teks, konteks, aqidah/ketuhanan (theology), ibadah (ritual), jejaring proses penerima dan penerimaan kitab suci (tarikh geneologis), kemasyarakatan (muamalah sosiologis), ahklak, alam semseta, awal dan akhir kehidupan dari kitab suci agama telah ada (eksis) membudaya (mainstream) di masyarakat tertentu (Tim Puslitbang Kehidupan Keagamaan, 2011:4-5).

Berpedoman pada Ketetapan Kriteria penentuan Paham dan Aliran Sesat yang dikeluarkan oleh MUI pusat, berdasarkan hasil Musyawarah Nasional tahun 2005. Kriteria tersebut dapat dijadikan sebagai rujukan dalam menganilisis sebelum dilakukan vonis terhadap kehadiran kelompok atau aliran yang dianggap sesat. Sepuluh kriteria yang dimaksud yakni:

1. Mengingkari salah satu dari rukun iman yang 6;

2. Meyakini atau mengikuti aqidah yang tidak sesuai dengan Al-Qur'an dan as Sunnah;

3. Meyakini turunnya wahyu setelah Al-Qur'an;

4. Menginkari otensitas atau kebenaran isi alQuran;

5. Menafsirkan al-Quran tidak berdasar pada kaidah-kaidah tafsir;

6. Mengingkari hadits nabi sebagai sumber ajaran Islam;

7. Menghina atau melecehkan atau merendahkan pada nabi dan rasul;

8. Mengingkari Nabi Muhammad sebagai nabi dan rasul akhir;

9. Mengubah, menambah dan atau mengurangi pokok-pokok ibadah yang telah ditetapkan oleh syariah seperti tidak berhaji ke baitullah, shalat wajib tidak 5 waktu;

10. Mengkafirkan sesama mulsim.

Proses transfer dan penerimaan serta penafsiran agama sesungguhnya sangat penting dalam mempengaruhi seseorang. Dari proses ini, pengertian tentang agama sebagai drive integrating motive, pribadinya akan tumbuh dengan pesan- pesan substantive yang diberikan saat pembelajaran mengenai ajaran agama yang ditafsirkannya. Jika penafsiran yang diajarkan itu memiliki ajaran yang baik, dalam arti moralitas individual dan kebaikan dalam kehidupan bersama, maka ia akan berguna bagi para pengikutnya, khususnya dalam soal mengontrol tindakan yang tidak menyakitkan bagi orang dan kelompok lain. Sebaliknya jika ajaran agama tersebut disusupi pesan-pesan pengejawantahan truth claim, dengan cara sendiri, termasuk dalam praktik-praktik keagamaan maka tentu akan mempengaruhi pula para pengikutnya. Oleh karena itulah dalam proses menjadikan pembelajaran agama sebagai drive integrating motive artikulasi para pemimpin kelompok keagamaan menjadi sangat penting. Artikulasinya pun sebenarnya dikehendaki sama dengan proses keyakinan penumbuhan kesadaran beragama bagi para pengikut kelompok keagamaannya (Humaedi, 2014:120-121).

Kehadiran seorang tokoh atau guru dalam sebuah kelompok yang dianggap menyimpang tentu memiliki pengaruh yang kuat bagi pengikutnya. Guru spiritual dianggap memiliki kelebihan utamanya dalam memperoleh pengetahuan atau pemahaman keagamaan didapatkan melalui wahyu atau ilham sehingga para pengikutnya menganggap sebagai yang suci sehingga memberikan perlakukan secara berlebihan bahkan mengkultuskannya sehingga apapun yang menjadi perintahnya tak mampu ia langgar.

Mengenai peran strategis pimpinan sekte ini, Michell Rogge dalam Psychology of Spiritual Movement sebagaimana dikutip oleh Masykur menuliskan bahwa setiap pemimpin atau guru mempunyai pengetahuan tentang sesuatu yang bisa diketahui sendiri oleh para muridnya. Akses ke realitas tersembunyi tersebut akan diberikan apabila pengikutnya setia kepada ajaran dan menerima otoritasnya, serta menyerahkan diri mereka kepadanya. Makin gelap tindakan guru makin benar ia dan makin harus diteladani, meskipun dengan menghinakan diri sendiri (Farida, 2015:112).

\section{METODE PENELITIAN}

Berangkat dari informasi tentang adanya pemahaman keagamaan yang dianggap tidak sesuai oleh masyarakat setempat. Maka peneliti melakukan penelusuran lebih lanjut untuk menggali sedalam mungkin informasi tentang keberadaan kelompok Majelis Ilmi Al-Amin di Kabupaten Boalemo dengan pendekatan kualitatif. 
Dalam penelusuran data beberapa tekhnik pengumpulan data yang digunakan yakni: melalui studi dokumen terhadap kelompok-kelompok keagamaan yang baru. Selanjutnya melakukan studi lapangan dengan melakukan beberapa kegiatan antara lain observasi terhadap keberadaan kelompok atau pengikut kelompok Majelis Ilmi Al-Amin yang tersebar pada dua kecamatan yakni Kecamatan Mananggu dan Kecamatan Paguyaman. Wawancara dengan sejumlah informan antara lain: Kabura (pembimbing Majelis Ilmi Al-Amin), Sarton A. Budi (pemimpin Majelis Ilmi Al-Amin), dan beberapa orang yang tidak berkeinginan disebutkan namanya sebagai informan kunci dalam memperoleh informasi terkait kelompok Majelis Ilmi Al-Amin. Di samping itu juga mendatangi beberapa lembaga terkait antara lain: Kesbang Politik dan MUI. Analisis data dilakukan secara secara mengalir dimana tedapat tiga komponen yang harus diperhatikan yakni (reduksi data, sajian data, penarikan kesimpulan atau verifikasi) dilakukan saling menjalin dengan proses pengumpulan data yang mengalir bersamaan (Zuriah, 2005:93).

\section{PEMBAHASAN}

\section{Majelis Ilmi Al-Amin: Profil dan Tokohnya}

Majelis Ilmi Al-Ilmi yang dimaknai sebagai tempat untuk memperoleh pengetahuan khususnya pengetahuan agama, awalnya didirikan oleh Yusuf Alhabsy pada Oktober 2007 yang dikuatkan dengan akta notaris. Yusuf Alhabsy merupakan ketua I dan sepeninggalnya dia digantikan oleh Ismail Sanusi sebagai ketua II. Kelompok Majelis Ilmi Al-Amin, awalnya muncul pada tahun 2007 di Desa Tabulo Kecamatan Mananggu, dalam Majelis Ilmi AlAmin selain Ketua juga ada yang disebut dengan pembimbing atau narasumber sebagai pucuk tertinggi yang bertugas memberikan pengajaran agama (pengajian) kepada pemimpin. Adapula yang disebut pimpinan kelompok yang bertugas memberikan pengajian kepada anggota atau pengikut. Keberadaan majelis ini hingga kini kurang lebih 20 tahun telah melakukan aktivitas pengajian dengan berbagai ajaran yang dikembangkan di dalamnya.

Majelis Ilmi Al-Amin berbentuk komunitas terbatas dan secara legal memiliki akta notaris, walau tidak secara hirarki memiliki susunan kepengurusan, namun penyebutan pimpinan tertinggi dalam majelis ini disebut narasumber atau pembimbing, lalu ada pemimpin dan pengikut. Akan tetapi pengendalian kelompok sebagai penanggujawab adalah ketua majelis.
Dalam Majelis Ilmi Al-Amin, posisi pembimbing atau narasumber tidak dapat digantikan oleh siapapun karena menurutnya dialah penerima wahyu, adapun pemimpin dipilih langsung oleh pembimbing di antara para jama'ahnya, demikian halnya pada posisi ketua dipilih secara langsung oleh pembimbing.

Majelis Ilmi Al-Amin mulai melakukan aktivitasnya sejak tahun 2007 hingga kini, pada dua desa yakni Desa Tabulo Kecamatan Mananggu, Desa Mustika. Namun setelah terjadi pengusiran dan pelemparan oleh masyarakat serta pembubaran oleh pemerintah maka aktivitas pengajian dipindahkan di Desa Mustika Kecamatan Paguyaman dan seiring dengan itupula keanggotaan mulai berangsurangsur keluar dari kelompok Majelis Ilmi AlAmin, sehingga aktivitas pengajian kepada anggota dialihkan di Desa Mutiara yang dipimpin oleh Bapak Sarton A. Budi. Pada aktivitas pengajian ini dibagi atas dua yakni pengajian untuk para pemimpin yang diberikan langsung oleh Burhan Sanusi selaku pembimbing atau narasumber dilaksanakan setiap malam rabu di kediaman Burhan Sanusi Desa Tabulo Kecamatan Mananggu. Sedangkan pengajian untuk anggota atau jama'ah diberikan oleh pemimpin, dilaksanakan setiap malam jum'at di kediaman Bapak Sarton A. Budi Desa Mutiara Kecamatan Paguyaman.

Untuk menarik jama'ah, maka berbicara hal ini harus dengan imam, demikian pula alqur'an memanggilnya hai orang-orang yang beriman, bukan hai orang Islam, demikian pula ilmu ini awal mulanya butuh orang beriman bukan orang-orang yang kafir, orang musryik, dzalim, munafik karena ini adalah cerita kegaiban dalam kegaiban yang dinamakan kegaiban Qulb jadi harus berdasarkan iman yang mantap, iman yang sempurna bukan sembarang iman, dan ilmu gaib adalah ilmu langsung dari Tuhan (Wawancara Sarton A. Budi, di Desa Mutiara, 16 Agustus 2017).

Ada beberapa alasan mengapa orang-orang tertarik untuk masuk dan duduk dalam pengajian Majelis Ilmi Al-Amin antara lain: percaya diri, artinya orang-orang yang bergabung menganggap apa yang disampaikan itu adalah suatu kebaikan dan kebenaran sehingga mereka tertarik untuk bergabung dalam Majelis Ilmi Al-Amin karena dianggap tidak menyimpang. Adapun pengikut yang bergabung dalam kelompok ini umumnya berprofesi sebagai masyarakat petani dan pedang. Perkiraan jumlah pengikut khususnya di Desa Mutiara Kecamatan Paguyaman yang aktif hingga 
saat ini diperkiraan berjumlah kurang lebih 50 orang (Wawancara Sarton A. Budi, di Desa Mutiara, 16 Agustus 2017).

Penuturan Kabura, selaku pembimbing bahwa dalam bermajelis maka tentu ada aturan yang diberlakukan di dalamnya, ada aturan yang disebut tata tertib bermajelis dan jangan melanggar, jika melanggar berarti tidak wajib dan tidak pantas mengikuti majelis terutama kelakuannya dan akhlak harus disesuaikan apa yang simak dengan apa yang akan dipraktikkan. Yang lainnya adalah bagaimana membangun hubungan dengan sesama sesuai dengan sunnah rasul, hubungan kepada Allah, jangan berlaku sombong, angkuh dan sebagainya. Kita harus seperti langit tinggi tetapi tidak sombong (Wawancara Burhan Sanusi, di Desa Tabulo Mananggu, 18 Agustus 2017).

\section{Burhan Sanusi alias Kabura: Dari Pedagang Kain Hingga Proses Penerimaan Wahyu}

Burhan Sanusi alias Kabura ( \pm 60 tahun), awalnya ia hanya seorang pedagang kain kecilkecilan di Pasar Mananggu yang menetap di Desa Tabulo Kecamatan Mananggu Kabupaten Boalemo Gorontalo, dialah yang bertindak sebagai pembimbing atau narasumber pada kelompok Majelis Ilmi Al-Amin. Kabura, sosok yang tidak memiliki pendidikan yang tinggi, hanya mengeyam pendidikan pada tingkat Sekolah Dasar (SD), namun oleh pengikutnya dianggap memiliki keluasan dalam hal pemahaman keagamaan dan mampu memberikan penjelasan-penjelasan keagamaan. Sesuatu yang membuat masyarakat terheran-heran dengan sosok Kabura hanya sebagai pedagang kain dengan kehidupan duniawinya begitu sukses dan hidup dalam kemewahan dan jika dikaitkan dengan profesi yang dilakoninya dianggap tidak sebanding dengan harta yang dimilikinya, pun dari sisi kehidupan rumah tangga Kabura memiliki dua orang istri.

Kabura adalah orang asli dan lahir di Desa Tabulo Kecamatan Mananggu yang diakuinya menerima wahyu dan akhirnya mengajarkan ilmu tersebut kepada masyarakat di Desa Tabulo. Di antara mereka yang mula-mula bergabung adalah dari kalangan kerabat dan keluarga, lalu menyebar kepada masyarakat luas, bahkan setelah kepindahanya di Desa Mustika karena adanya pelemparan dan pengusiran oleh masyarakat di Desa Tabulo, justru ajaran ini diterima bahkan hampir seluruh masyarakat Desa Mustika masuk dan duduk dalam pengajian Majelis Ilmi Al-Amin yang dipimpin oleh Kabura.

Kabura selaku pembimbing Majelis Ilmi AlAmin, diakuinya bahwa pendidikan formalnya hanya menengah ke bawah, namun di sisi lain memiliki pengetahuan dan pemahaman keagamaan yang cukup mumpuni sehingga beliau disebut sebagai pembimbing dan berhak mengajar kepada pemimpin mengenai ilmu-ilmu kegaiaban, karena ini adalah ilmu yang langsung dari Tuhan, walau ada yang mengatakan bahwa itu hanyalah hidayah tetapi menurutnya ini bukan hidayah karena hidayah itu masih di bawah dan ini lebih tinggi dari hidayah sehingga mengatakan bahwa ini adalah wahyu.

Pengakuan Kabura, bahwa ia memperoleh ilmu melalui proses mimpi secara langsung. Mula pertama setelah melakukan pernikahan kedua, disitulah ia mendapatkannya. Ia mimpi namun sebatas cahaya dan begitu cepatnya hanya sekejap mata datang, begitu sampai ia mengatakan bahwa aku mengantarkan wahyu, setelah itu kembali dengan cepatnya. Lalu ia (Kabura) mengejarnya (cahaya) itu dan entah kemana lalu ia mengatakan itu wahyu, dan cahaya yang dikejar itu menjawab dengan kata, ya. Peristiwa ini terjadi pada malam Rabu, dan selang dua hari yakni pada hari kamis setelah ashar, Kabura mendengar suara yang keras namun tidak dapat didengarkan oleh orang lain dan berkata aku yang datang malam itu mengantarkan wahyu melalui suara keras tersebut. Lalu sejenak ia terdiam dan setelah itu ia berangkat ke Manado untuk membeli dagangan. Ketika diperjalanan tepat pukul 16.00, dia terhenti di tengah jalan karena ada yang berbicara dengannya dari dalam melalui suara dengan menggunakan bahasa daerah bahwa aku yang datang pada malam itu yang mengantarkan wahyu dan kini aku akan menetap pada dirimu hinggi kini belum keluar (Wawancara Kabura, di Desa Tabulo Mananggu,18 Agustus 2017).

Dalam prosesnya, ada beberapa hal yang diajarkan yakni: Pertama diceritakan tentang kejadian alam semesta hingga akhirnya mengetahui semua nama-nama alam, berbicara alam lahut, alam malakut, alam arwah, dan sebagainya kurang lebih dua tahun dan dimahirkan tentang alam. Kedua setelah semuanya diceritakan dan apa yang ada di dalamnya di langit dan bumi, lalu dipindahkan pada kejadian tubuh manusia beserta apa yang ada di dalam tubuh manusia, ilmu ladunny, hati, tubuh, ruh dan rahasia. Berbicara tentang manusia berarti berbicara tentang tubuh, berbicara manusia berarti 
berbicara tentang hati, berbicara manusia berarti berbicara tentang ruh, dan berbicara manusia berarti berbicara tentang rahasia. Setelah mahir tentang kejadian manusia. Selanjutnya dipindahkan pada proses Ketiga tentang Alquranul Karim. Sedangkan ia tidak sama sekali mengenal huruf alquran karena dia bukan dari pesantren, huruf alifpun tidak diketahu, karena sudah menerima maka mulai menerima alqur'an walaupun belum semuanya dan dia pun menerima perintah untuk melakukan takziyah selama 2 tahun.

Pada proses ketiga ini, karena tidak memiliki dasar lalu diperintahkan untuk ta'ziyah maka ia menangis di tengah malam memohon dan meminta kepada Allah SWT, dimana pertama ia meminta untuk kemudahan dalam berbahasa khususnya bahasa Arab, selanjutnya bahasa Indonesia dan terakhir bahasa daerah. Ketiga bahasa ini ia minta secara langsung dalam dirinya, karena ia memang bodoh hanya berpendidikan Sekolah Dasar, akhirnya yang terjadi dalam permohonan itu tidak berapa lama kemudian ia diperintahkan untuk belajar mengaji, dan belajar secara otodidak tanpa ada guru dengan linangan air mata dan tidak berapa lama ia mampu mengaji tanpa diajari oleh seorang guru. Setelah mengetahui dan mampu membaca alquran dengan mahraj, tajwidnya dan ia sudah mengetahui secara keseluruhan, ia pun tetap melakukan takziyah bahkan sampai ke Gorontalo bahkan ia melakukan takziyah di mana-mana. Pada proses III ini pun ditempuh selama dua tahun. Keempat, Proses selanjutnya melalui suara ia diperintahkan untuk berhenti melakukan takziyah dan akhirnya mendirikan Majelis Ilmi Al-Amin di Paguyaman, kira-kira kurang lebih dari 7 tahun diikuti ribuan orang dan bahkan ia didatangi oleh polisi untuk memeriksa jangan sampai kegiatan ini menyimpang. Setelah mendirikan Majelis Ilmi AlAmin selama 7 tahun lalu terhenti, lalu ia mengangkat pemimpin untuk menyampaikan dakwah tersebut, sehingga status Kabura hanya sebagai pembimbing atau narasumber melalui Majelis Ilmi Al-Amin secara khusus bil khusus, salah satunya yang ada di Paguyaman. Pengikut yang tergabung dalam majelis ini hanya sekitar Gorontalo saja karena ilmu ini tidak boleh disebarkan luas, dan menyebar hanya pada orang-orang yang tergabung di dalamnya.

Majelis Ilmi Al-Amin: Pemahaman dan Ajarannya

Sebagai pembimbing Majelis Ilmi Al-Amin. Kabura dalam melakukan aktifitas pengajian, selain alquran dan hadits ada beberapa kitab yang dijadikan sebagai kajian yakni: Durratun Nasihin (mutiara nasehat), Tanbihul Ghafilin (mengingat kepada yang lupa diri), Minhajul Abidin (Imam Gazali) Ihya Ulumul Din (Imam Gazali). Adapun mengenai syariat, tarekat, hakekat dan ma'rifat, keempatnya telah ada dalam diri Kabura. Sedangkan penyebutan mahzab empat diberikan pemaknaan yang berbeda seperti Imam Hambali sebagai ahli hakekat, Iman Hambali itu lebih tinggi sehingga dinamakan penghambaan. Imam Maliki yang merajai lebih, Imam Syafi'i ahli sufi serta Imam Hanafi lebih pada hukum-hukum, keempatnya adalah benar namun dalam Majelis Ilmi Al-Amin tidak pernah membicarakan ini tetapi hadits apapun yang digunakan tetapi dijadikan sebagai dasar. (Wawancara Kabura, di Desa Tabulo 18 Agustus 2017).

Pemahaman keagamaan bagi kelompok Majelis Ilmi Al-Amin adalah bagaimana berjumpa dengan Tuhan dengan proses yang dilalui karena pada hakekatnya kita berasal dari Tuhan dan bagaimana bisa kembali pada Tuhan. Maka ada proses untuk menjumpai Tuhan dan tentunya melalui amalan-amalan saleh, bagaiamana beribadah dengan benar. Adapun pandangan Majelis Ilmi tentang syariat mengenai:

\section{Shalat.}

Shalat adalah ibadah tertinggi dalam Islam. Shalat sering disalahartikan sebagai "sembahyang". Sembahyang adalah ibadah atau pemujaan yang dapat dilakukan dalam bentuk, bahasa atau kondisi apapun. Permohonan doa seseorang anak untuk sebuah mainan adalah bentuk doa sama halnya dengan meditasi wali sufi. Di lain pihak, shalat dapat dilakukan hanya pada waktu tertentu, dengan cara yang sudah ditetapkan, dengan syarat-syarat tertentu. Shalat dilakukan lima kali sehari semalam. Shalat merupakan disiplin untuk semua muslim. Dengan mewajibkan shalat, Islam berupaya mendisiplinkan pemeluknya dan menjadikan mereka sadar selalu menyadari kehadiran Allah. Shalat menjelaskan waktu dan membiasakan kaum muslimin dengan irama hidup yang sehat, shalat memberikan kepuasaan jiwa dan emosi mengosongkan kesadaran diri dari kesibukan sehari-hari berkonsentrasi pada Allah dan kehadiran serta kehendak-Nya, berarti mengangkat diri ke yang mutlak dan universal (Faruqi, 1986:177-178).

saat menunaikan shalat hendaklah engkau selalu mengingat: apakah engkau suka jika termasuk kaum yang menunaikan shalat, tetapi 
pada hakekatnya mereka tidak shalat. Atau apakah engkau suka jika hatimu khusyu' dan ruh merasa sangat senang bermunajat kepada Rabb Jalla wa 'Ala. Kesemua ini sumbernya adalah ma'rifatullah (mengenal Allah), keagungan, keperkasaan dan kesempurnaannya (Arafah, 2012: 134).

Menurut Kabura, shalat itu ada zahirnya, ada batinnya. Dalam Majelis Ilmi Al-Amin pelaksanaan shalatnya (shalat lima waktu maupun shalat jum'at) tidak lagi terlihat oleh manusia, bukan meninggalkan tetapi meningkatkan karena Tuhan itu gaib dan butuh amal terhadap amalan gaib yang digaibkan kepadanya, dan dia tidak butuh dan tidak senang pada amalan nyata. Menurutnya karena amalan ini telah berada pada tingkatan-tingkatan khusus, sehingga tidak bisa disebarluaskan dan khusus orang yang beriman yang masuk ke dalamnya, jika belum beriman maka belum dapat disampaikan karena mengacaukan masyarakat.

Shalat bukan lagi tubuh yang kesana-kemari, tetapi shalat itu adalah dalam hati sebagaimana dinyatakan dalam alquran "يركذل ةولصنا مقأول" shalat itu bukan mengejarkan tetapi mendirikan, dan kira-kira apa yang didirikan di sini. Kalau bercerita tentang mendirikan maka harus berhubungan dengan Allah, sehingga shalat itu ada dialog antara Tuhan dan manusia artinya manusia telah melakukan dialog secara batin, sehingga shalat lima waktu tidak lagi dilakukan melalui gerakan tubuh karena telah dikerjakan oleh batin. Demikian pula shalat ke masjid itu tidak lagi dilakukan karena sudah ada dalam diri, kita inilah yang bekerja. Shalat itu intinya cuma satu tetapi mengapa harus repot dengan

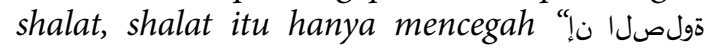

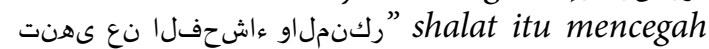
keburukan dan perbuatan dari kejahatan itu, tidak ada yang lain dan shalat bagaimana yang dapat mencegah kejahatan itulah pekerjaan batin yang dilakukan secara halus. Jadi shalat itu dilakukan secara batin bukan nyata karena Tuhan itu Gaib. Jika shalat itu dilakukan oleh tubuh itu artinya memperagakan saja, dan apa yang dilakukan itu sudah melalui qalbiyah (hati). Mengapa anggota Majelis Ilmi Al-Amin tidak kelihatan di masjid, karena ada yang dihindari yakni riya, karena ketika orang melihat kita artinya itu pamer atau riya dan ini dihindari sehingga kita bisa masuk pada tingkatan bhatin, sedangkan riya dan pamer itu adalah dosa dan kita jangan takut pada manusia tetapi takut pada Allah (Kabura, Desa Tabulo Mananggu, 19 Agustus 2017).

\section{Puasa.}

Pemahaman terhadap puasa dibagi dalam 3 tingkatanyaknishawmulawwam, shawmulkhawwas dan shawmul khawwasul bil khawwas. Puasa orang awam atau shawmul awwam. Puasa ini dipahami sebagai puasa yang hanya menahan makan, minum dan bercampur dengan istri. Kemudian shawmul khawwas adalah menahan seluruh anggota badan untuk tidak berbuat kejahatan di siang hari, dan selanjutnya shawmul khawwasul bil khawwas adalah menahan getaran hati untuk tidak berbuat.

Dalam Majelis Ilmi Al-Amin, implementasi puasa sudah dilakukan secara keseluruhan, ketiganya dikerjakan dan menjadi rahasia antara Tuhan dengan manusia berbeda dengan ibadah lainnya. Puasa yang sesungguhnya adalah menahan perkataan yang kotor, menahan pandangan mata. sedangkan shawmul khawwasul bil khawwas adalah puasa yang dilakukan dengan pendekatan batin, pada getaran hati, dan tidak kelihatan serta jangan sekali-kali tertuju kepada hal yang dilarang atau hal-hal fana yang akan hancur dan binasa.

\section{Zakat.}

Zakat terbagi atas tiga yaitu: zakat mal: melalui pembersihan harta sehingga sebahagaian harta harus dikeluarkan, zakat infaq: membelanjakan harta di jalan Allah dan zakat fitrah: mensucikan diri lahir dan batin. Dalam pelaksanakan zakat fitrah bagi anggota harus disalurkan ke sesama anggota karena mereka lebih wajib, namun ada pula menyalurkan zakatnya di masjid untuk membantu yang tidak mampu, bahkan Majelis Ilmi Al-Amin juga mengambil bagian tetapi lebih diutamakan kepada anggota dan ini dikatakan zakatul hawas, bukan zakat awam. Dalam Majelis Ilmi Al-Amin tidak ada istilah pengumpulan zakat fitrah, jika tiba waktu bulan puasa maka semua wajib membayarkan zakat fitrahnya kemanapun.

\section{Haji.}

Dalam pandangannya Majelis Ilmi Al-Amin, haji itu menyangkut pengorbanan, sedangkan yang lainnya adalah perjuangan. Haji sebagai pengorbanan untuk menyempurnakan yang lainnya yakni syahadat, shalat, puasa dan zakat, haji itu pengorabanan untuk mendekatkan diri kepada Allah Swt. Hingga kini anggota Majelis Ilmi Al-Amin belum ada yang ke baitullah untuk menunaikan ibadah haji walaupun mereka banyak yang mampu, tetapi mereka tidak akan berkunjung ke baitullah, namun pada hakekatnya sudah berhaji di sini karena masih banyak yang membutuhkan 
dan mengapa kita harus ke sana walau pada dasarnya memang harus berangkat tetapi pada hakekatnya sudah dilakukan karena ini peningkatan dan berangkat haji itu termasuk perbuatan riya dan pamer karena satu kampung dapat mengetahuinya. (Wawancara, Kabura 20 Agustus 2017).

\section{Majelis Ilmi Al-Amin: Pandangan Masyarakat dan Pemerintah}

Kehadiran Majelis Ilmi Al-Amin di Desa Tabulo Kecamatan Mananggu, memunculkan stigma yang negatif dari masyarakat maupun pemerintah. Sebahagian besar masyarakat tidak menyetujui bahkan mengatakan sebagai aliran yang menyimpang. Hal ini terjadi diawal-awal kemunculannya dalam melakukan aktivitas pengajian, bahkan pihak kepolisian secara langsung melakukan pengecekan terhadap apa yang dituduhkan oleh masyarakat terkait aktivitas pengajian yang diangap menyimpang.

Menurut pengakuan Kabura, setelah ia dipanggil ke masjid untuk menyampaikan dakwah dan dipertemukan dengan masyarakat, lalu ia berbicara maka keresahan masyarakat mulai redah karena apa yang disampaikannya itu mengandung kebenaran. Menurutnya, apa yang disampiakan itu justru tidak bertentangan dengan hadits bahkan oleh kepolisian mengatakan ini yang benar dan perlu diteruskan, bahkan menurutnya di antara mereka banyak yang menyesal karena tidak bergabung di dalamnya. Membicarakan suatu ilmu atau kebenaran memang banyak tantangan rasulpun demikian (Wawancara, Kabura 20 Agustus 2017).

Namun beberapa pandangan dari masyarakat bahkan anggota yang pernah duduk dalam pengajian mengatakan, bahwa di dalam Majelis Ilmi Al-Amin itu ada yang disebut istiqamah dan menjadi patokan dan pegangan bagi setiap pengikut yang sulit untuk dilepas dan sudah menjadi rahasia bagi mereka dan inilah yang membuat anggota lambat laun keluar dari kelompok Majelis Ilmi Al-Amin. Selain itu, ada beberapa hal yang dianggap tidak sesuai dengan apa yang dilakukan oleh masyarakat pada umumnya seperti tidak lagi mengerjakan shalat lima waktu bahkan shalat jum'at juga sudah tidak dilakukan, pelaksanaan puasa (tetapi anggota sudah meninggal) ketika bulan ramadhan ia tetap makan minum dan ketika ditanya mengapa demikian jawabannya bahwa puasa seperti itu adalah puasanya bagi orang-orang yang tinggi tingkatannya. Secara tidak langsung penjelasan yang disampaikan kepada masyarakat sangat bagus tetapi pada praktiknya tidak demikian, menurutnya puasa yang hanya menahan itu adalah puasa bagi orang awam semata (Wawancara " $K$ " di Desa Permata, 19/8/2017).

Pernyataan lain yang diungkapkan oleh seorang mantan anggota yang tidak ingin disebutkan namanya menuturkan:

Dulu waktu saya duduk (bergabung) saya senang karena lebih banyak menekan hawa nafsu utamanya hawa nafsu diniawi, jangan terlalu cinta dunia tetapi lebih banyak cinta pada akhirat. Oleh kerana itu harus menguasai hawa nafsu dulu, lalu pertama saya memperhatikan pembimbing ini bagaimana bisa menguasai amarahnya, tetapi lama kelamaan saya lihat orangnya justru banyak marah, sehingga saya merasa kharisma apa yang dimiliki orang ini. Dan disinilah saya berhenti dan akhirnya keluar, antara ucapan dan kelakukan tidak sesuai, selanjutnya jama'ah yang lainnya juga demikian ucapan mereka bagus namun perbuataanya tidak sesuai. Ajarannya bagus namun orang yang ikut itu tidak sesuai dengan pembicaraan dan ucapannya ketika melakukan pengajian "kon gagah ngoni dengan penjelasan tadi malam, kon ini hari so bagini", artinya ucapan dengan perbuatan tidak sesuai apa yang diucapkan malam ini tidak sesuai dengan apa dipraktikkan di siang harinya. Karena saya tidak setuju, maka saya berdiskusi dengan salah satu pengikut yang masih aktif lalu saya bertanya tidak mungkin kita naik tarekat lalu kita tinggalkan syariatnya, maka jawabnya tidak mungkin kita membawa tangga itu di bawah naik, maka secara otomatis tidak mungkin di tangga kedua akan turun lagi ke tangga pertama secara logika memang itu betul tetapi tidak mungkin ketika sudah menaiki tarekat lalu meninggalkan syariat. Justru orang yang bertarekat, syariatnya harus kuat dulu, tidak mungkin kita iman tanpa melalui dua kalimat syahadat, da kita mengimani siapa tentunya Allah dan rasul.

Pemahaman dan praktik syariat utamanya pada pelaksanaan shalat dan puasa inilah yang dianggap berbeda dan menyimpang oleh masyarakat. Di samping itu, ketika sang pembimbing atau narasumber telah memberikan pengajian kepada jama'ahnya maka ada imbalan wajib yang diberikan kepada "Sang Guru atau Sang Pembimbing" sebelum atau sesudah berupa amplop melakukan pengajian. Pengajian ini biasanya dilakukan di rumah salah seorang anggota majelis, 
dan ketika "Sang Pembimbing" telah berada di tempat duduknya maka para jama'ah memegang tangannya lalu memberikan "sesuatu" dan karena inilah para jama'ah banyak yang mundur dan keluar dan pada akhirnya terjadi pelemparan batu sebagaimana yang terjadi di Desa Mustika. Dan menurut pengakuan salah seorang anggota bahwa istiqamah ini rutin harus diberikan sehingga setiap pengajian harus memberikan kenang-kenangan, dan istiqamah ini sebagai kententuan, tetapi menurutnya mungkin itu tidak salah, bersedekah itu memang baik mungkin tujuannya untuk pengembangan kajian jama'ah dan itu pasti ada (Wawancara di Desa Mutiara 18/8/2017).

Adapun respon dari pihak pemerintah, bahwa aktivitas pertama kalinya dilakukan di rumah Kabura, hingga tahun 2009 dan selanjutnya kegiatan dipindahkan ke Desa Mustika Kecamatan Paguyaman karena adanya kasus pelemparan oleh masyarakat. Karena aktivitas yang dilakukan dalam Majelis Ilmi Al-Amin ini dianggap bertentangan, bahkan oleh Majelis Ulama Indonesia dan Kesbangpol yang pada saat itu dikepalai oleh Bapak Herman menanggap bahwa Majelis Ilmi Al-Amin sebagai aliran yang menyimpang sehingga dilakukan penindakan dari Kesbangpol bekerjasama dengan pihak MUI, Kementerian Agama, Kepolisian, Kejaksaaan dan masyarakat guna membubarkan tempat aktivitas yang dilakukan dalam Majelis Ilmi Al-Amin. Namun bukannya bubar, melainkan aktifitas dipindahkan pada salah desa di Kecamatan Paguyaman yakni Desa Mustika pada tahun 2009, namun berselang beberapa tahun karena adanya ketidakcocokkan bahkan dari sejumlah anggota majelis mulai keluar dan tidak lagi bergabung, maka kegiatan ini dipindahkan di Desa Mutiara Kecamatan Paguyaman, dan tetap dilakukan pengawasan dan pemantauan oleh pemerintah dan masyarakat karena sejauh ini kehadiran mereka tidak membawa pada konflik dan masyarakat tidak lagi terpengaruh bahkan semakin hari anggota semakin berkurang.

\section{PENUTUP}

Kehadiran kelompok keagamaan merupakan cerminan dinamika keberagamaan di Indonesia. Suatu aliran dan paham keagamaan terkadang mengklaim diri sebagai penyelamat umat dari dekadensi moral. Munculnya kelompok yang dianggap sempalan akan berpontesi melahirkan konflik, mereka hadir membawa paham dan praktik keagamaan yang berbeda dengan anutan kebanyakan umat (mainstream). Disisi lain, kehadiran kelompok atau paham yang berbeda ini akan membawa pada sikap destruktif. Kebhinekaan agama dan keimanan adalah kehendak Allah yang tak bisa ditolak atau dihindari, setiap orang berhak dan sepantasnya berbangga dengan agama dan keyakinannya tanpa harus menuding keyakinan orang lain sebagai kepalsuan dan kesesatan.

Kelompok Majelis Ilmi Al-Amin, salah satu bahagian dari dinamika keberagamaan. Melalui sang pembimbing mengklaim telah menerima hidayah, ilham bahkan menyebutnya sebagai "wahyu" yang diterimanya melalui proses dialog panjang antara dirinya dengan malaikat tentang ilmu kegaiban, lalu diperintahkannya untuk mengajarkan dan mengamalkan kepada orang yang beriman. Pemahaman keagamaan yang diterima oleh Burhan Sanusi yang lebih akrab disapa dengan Kabura sebagai "Sang Pembimbing" meliputi: 1) prnciptaan alam, 2) penciptaan manusia, ilmu ladunny, 3) alquranul karim, dan 4) perintah untuk melakukan takziyah.

Setelah menerima berbagai pengetahuan dan pemahaman keagamaan, maka melalui Mejelis Ilmi Al-Amin inilah Sang Pembimbing melakukan kajian/pengajian kepada sejumlah anggota yang dimulainya sejak tahun 2007 hingga kini, walau kelompok ini dianggap menyimpang oleh pemerintah melalui MUI dan Kesbang Politik.

Ada beberapa ajaran yang dinilai menyimpang utamanya pada pemahaman dan pelaksanaan syari'ah seperti pada pelaksanaan shalat yang hanya dilakukan secara batiniah baik shalat lima waktu maupun shalat jum'at. Selanjutnya pada pelaksanaan puasa yang telah berada pada tingkatan hawas bil hawas serta berhaji tidak peerlu lagi ke baitullah dan adanya prinsip "istiqamah" yang rutin dilaksanakan dan menjadi kewajiban setiap anggota disetiap pengajian. Oleh karena itu, stigma penyimpangan dari masyarakat maupun pemerintah ditujukan kepada kelompok Majelis Ilmi Al-Amin, bahkan mendapatkan tindakan kekerasan berupa pelemparan dan pengusiran oleh masyarakat setempat.

\section{UCAPAN TERIMA KASIH}

Peneliti mengucapkan terima kasih kepada seluruh informan yang telah memberikan data dan informasi terkait Kelompok Majelis Ilmi AlAmin. Dan kepada pengelola Jurnal Al-Qalam Balai Penelitian dan Pengembangan Agama Makassar untuk memuat tulisan ini. 


\section{DAFTAR PUSTAKA}

Arafah, Sitti. 2012. Zikir dan Tanda-Tanda Kematian dalam Naskah Haqeqakna Sampajang, AlQalam, Volume. 18 Nomor. 1 Edisi Juni 2012: 134.

Connoly, Peter (ed). 2016. Aneka Pendekatan Studi Agama. Cet. I; Yogyakarta: IRCiSod bekerjasama dengan LKIs.

Farida, Anik. 2015. Memahami Aliran Quraniyah di Kabupaten Bandung Barat Jawa Barat: Dari Problem Teologis hingga Ekonomi, dalam Jurnal Penamas, Volume 28 Nomor 1 Edisi April- juni 2015.

Faruqi dan Lamya. 1986. The Cultural Atlas of Islam, New York: Macmillan Publishing Company. Diterjemahkan oleh Ilyas Hasan dengan Judul Atlas Budaya Islam, 2003, Cetakan IV; Jakarta: Mizan.

Hakim, (ed). 2009. Direktori Aliran, Faham dan Gerakan Keagamaan di Indonesia, Cet. I; Jakarta: Puslitang Kehidupan Keagaman Badan Litbang dan Diklat Departemen Agama.

Humaedi, Ali. 2014. Kerusuhan Sampang: Kontestasi Aliran Keagamaan dalam Wajah Kebudayaan Madura, dalam Jurnal Harmoni, Volume. 13 Nomor 2 Edisi Mei-Agustus, 2014.

Nuhrison, (ed). 2009. Aliran/Faham Keagamaan dan Sufisme Perkotaan, Cet.1; Jakarta: Puslitbang
Kehidupan Keagamaan Badan Litbang dan Diklat Departemen Agama.

Nugraha, Firman. 2016. Eksistensi Amanat Keagungan Ilahi (AKI) Perspektif Fungsionalisme Durkheim, dalam Jurnal AlQalam, Volume 22 nomor 2, Edisi Desember 2016.

Tim Puslitbang Kehidupan Keagamaan, 2011. Buku Panduan Pengangan Aliran dan Gerakan Keagamaan Bermasalah di Indonesia, Jakarta: 2011.

Saprillah, 2016. Stigmatisasi Terhadap GAFATAR di Sulawesi Tenggara, dalam Jurnal Mimikri, Volume 2 Nomor 1, Edisi Juni 2016.

Saprillah, dkk. 2017, Multikuturalisme dan Problem Keagamaan Masyarakat Urban; Yogyakarta: Lintas Nalar.

Sunar, Muhammad Subair. 2012. Inkarnasi Nabi Khaidir? Aliran Sempalan Puang Malea, dalam Jurnal Al-Qalam, Volume 18 Nomor 1 Edisi Januari-Juni 2012.

Scharf, R. Betty. 2004, Sosilogi Agama, Edisi 2, Cet. 1; Jakarta: Kencana.

Ubaid Abdullah dan Bakir Muhammad (ed), 2015, Nasionalisme Islam Nusantara, Cet; I; Jakarta: Kompas Media Nusantara.

Zuriah, Nurul. 2009, Metodologi Penelitian Sosial dan Pendidikan, Cet.3; Jakaarta: Sinar Grafika Offset. 